\title{
Staff-wide Mentoring of Pre-service Teachers: Benefits and Barriers
}

\author{
Doug Smith \\ University of Saskatchewan
}

\begin{abstract}
School-university partnerships are purported to develop the collegial support needed for any educational change. They may also surmount barriers between pre-service and inservice teacher education. In this school-university partnership study involving staff-wide mentoring of pre-service teachers as a change agent, the writer outlines the benefits to pre-and in-service teachers and the barriers encountered that prevented them from fulfilling partnership promise. Pre-service teachers achieved desired internship outcomes and change-resistant teachers developed collegiality and support. Central administration interference and lack of principal leadership created barriers. Suggestions for overcoming the barriers are offered.
\end{abstract}

Can Canadian teacher educators simultaneously support school staffs and pre-service teacher development in an educational partnership? Can principals build self-renewing teacher growth through staff mentoring of pre-service teachers? By creating professional partnerships between teachers and pre-service student teachers, principals may create staff rejuvenation through a formal mentorship program. The Canadian context for school-university partnership is limited in comparison to that of the United States, where the merits of these programs have been studied for the last decade (Goodlad, 1993; Holmes Group, 1990). Educators in the Centre for School-Based Experiences, College of Education, University of Saskatchewan, had an opportunity to explore these questions.

The impetus for exploring a university-school based partnership came from a Saskatchewan school principal and his staff interested in selfrenewal. The "development of others" is listed as one of the ten vital skills for effective school leaders (Terehoff, 2002). Our college supported the

Doug Smith, a Professor of Curriculum Studies, has interests in school-based experiences, Aboriginal education, and development of professional portfolios. 
school-college partnership during a 16-week internship because it allowed us to explore teacher education options, enhance intern (student teacher) growth in a junior high school setting, and support educational improvement for teachers. The partnership had the potential to create learning opportunities for all.

To engage change-resistant and change-welcoming teachers through multi-teacher student teacher mentoring, a junior-high school principal asked that our college have 6 pre-service intern teachers complete internships in his school. To maximize staff involvement, he stated that all teachers would become either primary (co-operating) or supplementary (associate) intern mentor teachers. The co-operating teachers (co-ops) would interact with the intern about $60 \%$ of the time; associate teachers would offer intern-mentoring support for the remaining time. The staff would experience professional development as members of intern mentoring teams and each intern would receive feedback from several teachers.

In preparation for intern mentoring, the principal planned to give his staff instruction and practice in using teacher growth plans, cognitive coaching, and preparation of professional portfolios. He predicted that both pre- and in-service teachers would benefit from the topics.

Two members of the college centre met with the principal and his staff to plan the partnership. They negotiated an agreement with the school staff, listing roles and responsibilities for all participants. The document specified how both parties would proceed to achieve school in-service goals, and internship outcomes. Being sensitive to the sharing of power over interns between the school and the college, the college educators made the interns aware of the project, informed them of their rights to withdraw from the placement, and kept close contact with them throughout the internship.

Research questions were: What are the participants' perceptions of the barriers (forces that keep change from occurring) and benefits (opportunities for change) of the innovation to pre- and in-service teacher development? The research purpose was to examine the nature of staff-wide mentoring on pre- and in-service teacher improvement.

To provide the background for this study, this article describes related research, the Saskatchewan internship program, the school, and partnership objectives. The Procedures section summarizes participants involved, and data collection and analysis methods. Findings contain data collected during and after the innovation. This includes perceptions from the six sets of informants and the data listed and discussed subsumed under 
D. Smith

Benefits and Barriers. Lessons Learned presents a discussion section and a conclusion derived from the discussion.

\section{Related Research}

The research background begins with a brief examination of the role of the principal and staff development literature. Educational partnerships and professional development schools (PDS) literature, however, provide the main theoretical frame for the study.

\section{Principal's Role}

Researchers reveal that the principal's leadership role in partnerships is key (Trubowitz \& Longo, 1997). Pajak and Glickman (1989) advise that school leaders must plan, motivate, and organize to encourage teacher growth. Partnerships are enhanced when principals develop teacher collegiality (Grimmett \& Crehan, 1992; Prawat, 1993), create communities of learners (Sheppard, 1996), and build school team structures (Reitzug \& Burrello, 1995).

\section{Staff Development}

Principals can improve staff development by: creating an environment for adult learning (Terehoff, 2002), nurturing collegial relationships (Rymer, 2002), supporting a learning community (Slick, 2002), and by using strong communication skills (Blase \& Blase, 2001). They must recognize that change is collaborative as well as individual (Weasmer \& Woods, 1999) and encourage change by maximizing mentor training and ongoing support (Ganzer, 2002). They can overcome progress barriers by challenging hidden assumptions (Sparks, 2002) and deal with resistant teachers by modeling interpersonal strategies (Whitaker, 1999). Hargreaves and Dawe (1990) caution that when principals force teacher interactions on change-resistant teachers, they may create a contrived collegiality rather than open, trusting, and supportive relationships.

\section{School-University Partnerships}

In Tomorrow's Schools (Holmes Group, 1990) and the Carnegie Reports (Carnegie Forum, 1986), Holmes and others called for collaboration between higher education and K-12 schools. They believed that school/university partnerships would bridge the gap between university theory and school 
practice. Collaboration supporters (Goodlad, 1993; Liberman \& Miller, 1990; Teitel, 1997; Watson \& Fullan, 1992) suggested that these partnerships were vital to school improvement, initial teacher preparation, and teacher professional development because they provided opportunities for applying and conducting educational research in an appropriate context. Others noted that the partnerships promoted teacher professionalism, development of mentor teachers (Harriman, 1998), and staff collegiality (Richardson, 1998). Researchers suggest that educational partnerships improve both initial teacher preparation and professional development for veteran teachers (Himel, Hall, Henderson, \& Floyd, 2000; Maxson \& Schwartz, 2001) and revitalizes veteran teachers by decreasing their isolation (Sandholtz \& Dadlez 2000). Factors hindering schoolcollege collaborations were: time commitment (Clarken, 1999), conflicting dual role relationships (Vare, 1997), and lack of support in central administrative governance structures (Hackmann \& Berry, 1994). Partnerships languished because the school and university central administrators failed to provide the time, rewards, resources, or policies needed to fulfill the new duties. For example, university partners often discovered that work in schools did not gain university tenure and promotion rewards.

\section{Professional Development Schools}

The Holmes Group (1990) promoted Professional Development Schools (PDS) in $\mathrm{K}-12$ settings as a way of combining university educators' theoretical knowledge and research skills with the practical experience of classroom teachers. Other PDS goals were: to maximize student learning, to support professional teaching practice, to encourage educational research, and to enhance the professional education of novice and veteran teachers (Holmes Group, 1990).

But the goal of university educators and K-12 teachers working toward common ends in Professional Development Schools has rarely been reached (Valli, Cooper, \& Frankes, 1997). Explanations for failing to fulfill the PDS promise included: lack of focus on professional development leadership and policy (Ross, Brownell, Sindelar, \& Vandiver, 1999), fragile collaborative relationships (Abdal-Haqq, 1998), lack of resources, and scheduling and organizational problems (Sandholtz \& Dadlez, 2000; Teitel, 1994). In addition, some professors, viewing themselves as research scholars, followed their own agendas in schools rather than serving the needs of K-12 teachers. Similarly, some teachers failed to overcome their attitudes of mistrust toward university educators (Teitel, 1994). 


\section{The University of Saskatchewan Internship Program}

After completing two years of university arts or science courses, pre-service teachers (interns) enter the College of Education to complete a two-year program. They complete the 16-week internship in the fall term of the second year. Interns placed in schools gradually take on the role of the teacher, growing from a daily single lesson to 2 weeks of full-time teaching. Individual co-operating teachers in the host schools, coach, advise, and evaluate each intern through daily supervision. The college supervisor observes, and provides comments to the intern once a month. In addition, the supervisor may counsel the intern or co-operating teacher as needed. The supervisor also leads four monthly internship seminars for groups of co-op/intern pairs. The seminar topics include classroom management, planning, presenting, and questioning and responding to students. Two peer groups (one for interns, one for co-ops) also use seminar time to discuss issues of concern to each of the groups. During the formative evaluation of the third seminar, both intern and teacher share perceptions of the interns' strengths and areas needing development. Then they set professional goals for the final month. The co-operating teacher completes a final intern evaluation at the end of the fieldwork. Interns also complete a classroom management course run concurrently with the internship. As well, interns create a professional portfolio documenting their growth as teachers. Using the key words collect, select, and reflect to show the three steps in building a portfolio, the interns collect evidence of teaching, select items that illustrate their experience, and reflect on their personalized learning. They, as others, form a document collection that shows the scope and quality of their teaching and learning over time (Wolf, Whinery, \& Hagerty, 1995).

Swiftview (a pseudonym) is a junior-high school with 300 students, 17 staff, and 4 paraprofessionals. The principal and staff agreed that they would all work co-operatively with the six intern teachers to advance the teaching and learning of students, and pre-and in-service teachers.

\section{Partnership Objectives}

Besides utilizing intern mentoring teams consisting of co-operating and associate teachers, the staff expected the principal to instruct them in cognitive coaching (strategies that invite self and others to shape and reshape their thinking and problem solving, Costa \& Garmston, 1994), portfolio development (see above), and teacher growth plans (teachers annually assessing and identifying their learning and improvement needs, Alberta Teachers'

Association, 2001). 
The staff development topics complemented our typical internship process and supported teacher education research. For example, cognitive coaching was an extension of our existing intern supervision. Research noted that pre-service teachers with mentors trained in cognitive coaching were more concerned with student needs than their own performance (Burk, Ford, Guff, \& Mann, 1996). Similarly, both newly hired teachers in the school and interns were expected to receive instruction in preparation of professional portfolios as a self-directed approach to professional development. In addition, the objective for staff members to identify goals for teacher growth plans would echo interns' selecting teaching targets for critical observation

\section{Procedures}

College researchers had previously supported and monitored two similar schoolcollege partnerships. Findings from these experiences guided our selection of flexible interns, an experienced college supervisor, and formation of a schoolcollege agreement outlining mutual goals, roles, and responsibilities for the partners.

The agreement stated that a co-operating teacher plus one or more associate teacher(s) would mentor each of the six interns; one teacher would facilitate the assignment of interns to teachers in the internship; and the principal and vice principal would instruct all participants in cognitive coaching, professional portfolio construction, and teacher growth plans during four staff meetings. The college supervisor, and former principal of the school, would review fundamental teaching skills for all participants during internship seminars, attend all 7:45 a.m. monthly staff development meetings, and provide monthly oral reports about the innovation to the college researcher.

Data collected by the researcher during the 16-week internship included four college supervisor reports delivered in person once a month, and three informal phone call discussions with the school principal.

\section{Data Collected at Term-End}

- Interns' final evaluation reports

- Three focus group 1-hour interviews (6 interns, 6 co-ops, 8 associate mentors)

- Two individual 1-hour interviews (principal, college supervisor). 
The research questions examined benefits and barriers in the partnership. All data were recorded, entered on computer, transcribed, collated under the themes, and then analyzed according to grounded theory (Glaser \& Strauss, 1967). Finally, we triangulated information collected during and after the innovations from the various participants to confirm findings.

\section{Findings}

In this section, we describe the participants' perceptions of benefits and barriers. The findings include information collected during the internship and term-end data from the five sets of informants (interns, co-ops, associate mentors, principal, college supervisor).

\section{Benefits}

\section{Support and Collegiality}

All participants identified the development of mutual support and collegiality as the most pervasive effects of the partnership. They described a network of supportive interrelationships linking intern to intern, intern to teacher, teacher to teacher, and intern-teacher-college/supervisor-principal connections. Below they provide details that show how they began to view their colleagues as members of an inclusive team.

The interns described support as: "welcoming, fantastic from all, giving and sharing." Teachers characterized support as: "creating a better atmosphere, moving away from YOUR problem to OUR problem, and giving each other opportunities for success." In agreement with other research, change grew through the development of mentor teachers (Harriman, 1998), ongoing support (Ganzer, 2002), and by building school team structures such as the co-op-associate mentoring teams (Harriman, 1998; Reitzug \& Burrello, 1995).

All participants showed collegiality through more "teacher discussion, mutual planning, opportunities to learn," and "feeling moved to share." They also used the terms camaraderie, staff cohesion, and working as a team to express collegiality.

Teacher actions illustrating collegiality at term-end included:

wanting time out of class to discuss and plan team teaching, volunteering to provide student tutorials after normal hours, and bringing resistant teachers 'onside' as active team members. Echoing others (Grimmet \& Crehan, 1992; Reitzug \& Burrello, 1995; Richardson, 1998; Trubowitz \& Longo, 1997), the interns and teachers stated that support and collegiality made them feel 
"encouraged, responsible, and part of the school-wide program." In contrast to our findings, Hargreaves \& Dawe (1990) caution that principals' top-down directives to foster teacher interactions may create "contrived collegiality" rather than a teacher-generated open, trusting and supportive relationship.

\section{Initial Instruction in Cognitive Coaching}

All participants agreed that the principal's initial instruction in use of cognitive coaching questions assisted interpersonal communication as it "broke down barriers" (interns, co-ops), "put all in the same playing field" (principal), "enabled interns to talk to students in a non-confrontational way," and "accelerated growth of professional relationships" (associate mentors). However, as seen in the Barriers section, after positive initial impressions, the perceptions about cognitive coaching instruction became negative. It should be noted that the college supervisor modeled a developmental approach to supervision rather than cognitive coaching.

\section{Preparation of Intern Teachers}

Midterm, final internship evaluation reports and interview data confirmed that interns successfully completed their internship. As noted in the PDS and partnership research, this collaboration enhanced the professional growth of novice teachers (Goodlad, 1993; Holmes Group, 1990; Watson \& Fullan, 1992). They displayed competent teaching skills, useful unit-plan construction, extracurricular leadership, and success in all aspects of their full-time teaching ( 2 weeks). Four of the six interns described their intern experience as "tops." Two interns qualified their "good" experience. One explained she had a subject specialty different from her co-op and she felt less bonded with him. Similarly, due to a scarcity of music classes offered in Swiftview, a music major intern had to complete her internship in two schools. She felt "less connected" because of her time spent outside Swiftview.

Associate mentors enhanced intern growth. All participants agreed that they "added to intern evaluations, provided intern challenge in teaching diverse subjects, and enabled interns to follow student cohorts through the daily timetable." In contrast to the single exemplar of one co-operating teacher, they provided interns with a range of experienced teacher models (Sandholtz \& Dadlez, 2000). 


\section{Enhancing Teacher Development}

The principal motivated all staff to participate in the partnership. Co-ops noted that resistant teachers had moved from isolation to engagement. End-of-term data showed that the principal had attained his objective of motivating his mix of eager and resistant teachers through participation in a school-wide mentoring team.

The participants described the college supervisor as "supportive, dedicated, accommodating, able to see the larger educational picture, and crucial to the partnership." In contrast to Vare's (1997) supervisor with dual role dilemmas, he successfully combined roles as college supervisor and staff developer by leading seminars, assessing interns, and contributing to staff meetings. He spent long days in the school to complete his high maintenance role. College educators need to constantly monitor the balance between supporting an innovation and not neglecting the college supervisors' internship responsibilities. As others have noted (Clarken, 1999), the high time and commitment demands of the partnership on the college supervisor must be weighed against staff and intern development gains. By contributing countless hours of volunteer time and effort, this college supervisor successfully combined both roles, but it is unrealistic to expect that others will be that generous.

\section{Barriers}

Notwithstanding benefits to teacher growth, the partnership experienced problems. The principal's health, central administrative interference, and intern/ teacher placement mismatch, built barriers that blocked teacher improvement.

\section{Principal Leadership}

Although the principal had developed an ambitious staff development plan that complemented aspects of the internship, he was unable to deliver his intended instruction. The partners met in a spring, pre-internship meeting. Knowing that small-step innovations were successful, we questioned the principal about the feasibility of planning an overly ambitious agenda of three staff development targets plus staff-wide intern mentoring. As he and his vice-principal had training in these strategies, he assured us that the multiple innovation goals were not excessive.

By late fall, however, the principal had to explain how three barriers had erupted that blocked teacher development in cognitive coaching, portfolio 
construction, and teacher growth plans. First, in late September, he had developed a debilitating medical condition that caused him to miss several of his scheduled instructional staff meetings. Consequently, he, like others (Ross, Brownell, Sindelar, \& Vandiver, 1999), was unable to act as the instructional leader. After the principal's lively introduction to the questioning patterns used in cognitive coaching, participants expressed disappointment: "It started with a bang then died quickly" (co-ops), "more instruction was needed" (associate mentors), and "it was not used in mentoring conferences" (interns).

\section{Central Administration Interference}

Second, the central administrators transferred his co-instructor (the viceprincipal) to another school during the summer. Lacking expertise in the three topics, the new vice-principal could not provide the predetermined staff instruction. Third, without previous consultation, the school division central administration declared that all schools, including Swiftview, would devote staff meetings to developing computerized evaluation as their fall, system-wide staff development goal. This top-down directive usurped the staff development agenda. It stole the time needed to implement the innovation. With crowded teaching schedules, there was no time for additional staff meetings. Hackmann \& Berry (1994) note that school division governance structures lacking school support hinder educational renewal. Other reasons for failed partnership promises included scheduling and organizational problems (Sandholtz \& Dadlez, 2000; Teitel, 1994).

The planned instruction was limited to a college supervisor briefing about portfolios for interns, reminders to "collect" portfolio artifacts, and two beginning teachers sharing their portfolios as models. However, as an associate mentor observed, "Teachers did not receive instruction or encouragement to develop professional portfolios at staff meetings." Lacking instruction, teachers did not develop teacher growth plans and staff development was minimal.

\section{Intern/Teacher Match}

While all participants generally agreed that associate mentors assisted intern growth, some relationships were less helpful. For example, the special needs teacher, an associate teacher, needed all her time to attend to students.

Therefore, while interns in this room had interesting challenges, they received little mentoring from the busy teacher. Additionally, two interns expressed difficulty in consolidating "fragmented feedback from multiple observers." Two other interns with Language Arts majors had difficulty finding time to teach with 
the Language Arts teachers who were in constant demand as associate mentors. The small school staff did not have the two or three teachers with subject specialization to match each intern's subject major. These effects show how the particular context determines the intern experience and how college educators must modify the program to meet individual intern needs.

\section{Lessons Learned from the Partnership}

Although the school-college partnership model has strong potential for teacher change, participants identified benefits and many barriers that emerged in this collaboration. They are discussed below. The key benefit of the innovation (all participants) was in building mutual support and in increasing group collegiality.

\section{Collegiality and Support}

The project participants, like others (Borthwick, 1995; Bromfield, 1999; Patterson, Michelli, \& Pacheco, 1999), found that collaboration and working in groups (Terehoff, 2002) broke down traditional barriers between pre- and inservice teacher education, and enhanced collegial interaction among experienced teachers (Teitel, 1997). Working toward a common goal appeared to enhance pre- and in-service teacher collegiality.

Evidence of interns, co-ops, associate mentors, and others being supportive is found in their references to "giving, sharing, and giving others opportunities for success." Resonating with research, all participants noted that the ongoing support (Ganzer, 2002), and supportive school-wide team structures (Harriman, 1998; Reitzug \& Burrelo, 1995), fostered positive change (Harriman, 1998).

Interns achieved desired internship outcomes by engaging in careerlong teacher education and collaborative activities with the experienced teachers. Reinforcing Boles and Troen's (1994) conclusions, this partnership appeared to provide opportunities for both parties to share goals, sustain involvement, work on teams, improve professional relationships, and draw in withdrawn teachers. For example, these staff developers asked why teachers feel excluded and used the information in their plans for change. One resistant teacher explained he felt disconnected and redundant because his teaching job description and the school mission had changed since his initial hiring. Staffwide mentoring made him feel needed again (associate mentor).

Focus group and individual interview data also mentioned the college supervisors' strong contributor to collegiality. While he was willing to lead internship seminars and contribute to the early morning staff development 
meetings, other college supervisors may not be. When considering future or more numerous partnerships, educators must consider the time demands of such work and the fragile nature of depending on college supervisor volunteers (Holmes Group, 1990; Ross et al., 1999).

Although these participants discussed collegiality in positive terms, Hargreaves and Dawe (1990) emphasize the dangers of contrived collegiality. They explain that the principal's leadership is often needed to initially foster collegial relationships, but teachers need to create their own collegiality as part of a collaborative culture. They add that excess administrative control of teacher interaction will undermine the elements of trust and support. As it can disempower and deprofessionalize teachers, educators should encourage teacher control of collegiality.

\section{Engaging Resistant Teachers}

Involving associate as well as co-operating teachers with intern mentoring helped engage resistant teachers. The principal and college supervisor noted that the collaborative and collegial support fostered by the innovation decreased teacher isolation. Professional discussion with colleagues increased as they shared responsibility for intern mentoring (co-ops). This involvement appeared to move the resistant teachers toward positive change. Associate mentor focus group reports indicated that they had become "team players." Perhaps, the principal's shared leadership with teachers in planning developed collaboration relationships (Terehoff, 2002) and the collegial collaboration demanded by staff-wide mentoring led teachers to think about improving their own teaching (Sandholtz \& Dadlez, 2000).

A researcher reflecting on 15 years of teachers' contributions to school improvement research alerted the present researcher to other interpretations. $\mathrm{He}$ noted that teachers might give the impression that they are using aspects of an innovation when they are not. The researcher concluded that teachers are resistant to innovations because they are most often recipients rather than initiators of change (Rutherford, 1986).

\section{Intern Preparation}

Many of the interns expressed satisfaction in being able to work with the pool of interns, co-ops, and associate teachers at one site. Interns valued the emotional support of peers, the observations of experienced teachers, and the mentoring by teachers from several disciplines. Mirroring High School level interns who need to focus on a single subject, two interns disliked the 
"fractured feedback" that came from having more than one mentor. This researcher and others (Sandholtz \& Dadlez, 2000) note that while elementary and middle years' interns may initially favour mentoring by a co-op from a single subject specialty, over time concern about subject specialization lessens. Further, Saskatchewan teacher education graduates (elementary, middle years, or rural K-12 schools) often teach four or five different subjects. Consequently, Colleges of Education should encourage interns to increase their employment prospects by valuing multi-discipline mentoring.

\section{Barriers}

The barriers to a successful partnership implementation included, incomplete principal leadership, lack of central administration support, and mismatched intern/teacher placements. We examine the principal first.

\section{Principal Leadership}

Principals working toward a few staff development goals increase their possibility of success. Large-scale change as outlined by Holmes (1990) and others, and as attempted in this school, is more difficult to implement. Partnerships need small, reasonable goals to work toward over several years, so that the participants have enough time to implement new measures, receive mentoring from others (Ross et al., 1999), build stable relationships and reflect on actions.

The principal's painful medical condition caused him to be absent from his staff development duties and other functions. With adequate resources for the innovation, the school could hire an instructor of the three topics.

\section{Central Administration Policy and Support}

The implementation progress stopped when the central administration transferred an instructional leader (vice-principal) to another school, and when they replaced the school staff development plan with a central office agenda. To overcome barriers: check assumptions about College and School Administration supports; inform central administrators about school staff development plans; seek their support; develop and enact partnership policy guidelines to avoid the problems of staff transfer, time use, funding, scheduling, and organizational details (Teitel, 1994); develop collaborative leadership and ensure that the principal's authority is not undermined by others (Sparks, 2002). 


\section{Intern Placement Options}

All interns successfully completed their internships while sharing support with peers and being mentored by a pool of experienced teachers (co-op and associate mentors). Five interns benefited from having multiple mentors, but some interns, preferring a close relationship with one co-op, disliked response from several mentors. While considering the pros and cons of placement alternatives, perhaps the most human choice is for interns to have options to suit their needs. For example, in this study, we arranged for one intern to replace the mentoring team with a single mentor.

\section{Conclusions}

These college educators supported both pre- and in-service teacher developments but the principal met several barriers that limited his attempts to encourage teacher growth. Moreover, this school-college partnership provided an opportunity to study changing roles, principal leadership, and investigate both school staff renewals and partnership-based teacher preparation. Benefits included collegial support-a necessary underpinning for any educational change process (Poole \& Okeafor, 1989)—engagement of resistant teachers, and intern experience with staff-wide mentoring. The participants speculated, however, that external control (principal-directed) could create contrived collegiality rather than professional (teacher-directed) collaboration. As reported in other less successful ventures, this collaborative partnership was hindered by lack of central administration support, the lack of principal leadership, and organizational problems. To surmount these barriers, schoolcollege planners need to:

- $\quad$ study how to work with each other (Ross et al., 1999);

- create guidelines to help teacher and teacher educators move closer to targets;

- address change in small steps (Gersten, Vaughan, Deshler, \& Schiller, 1997); and

- $\quad$ reorganize structures and provide time for such activities (Goodlad, 1993).

We can only improve schools by exploring alternatives. The study of total staff mentoring in a school-college partnership was part of this exploration. 
D. Smith

\section{Acknowledgements}

Grateful acknowledgments to Lynne Bayne, Blaine Dahl, Robert Paul, Laurie Leonard, Sam Robinson, teachers, interns, and reviewers.

\section{References}

Abdal-Haqq, I. (1998). Professional development schools: Weighing the evidence. Thousand Oaks, CA: Corwin.

Alberta Teachers' Association (2001). Teacher Growth, Supervision and Evaluation. Retrieved April 11, 2003 from http://www.teachers.ab.ca/ publications/monographs/

Blase, J., \& Blase, J. (2001). The teacher's principal. Journal of Staff Development, 22(1), 22-25.

Boles, K., \& Troen, V. (1994). Teacher leadership in a professional development school. New Orleans, LA: Annual Meeting of the American Educational Research Association (ERIC Document Reproduction Service No. ED 375 103)

Borthwick, A. G. (1995). School-university-community collaboration: Establishing and maintaining partnerships for school improvement. San Francisco, CA: Annual Meeting of the American Educational Research Association. (ERIC Document Reproduction Service No. ED 385 922)

Bromfield, M, (1999). School-college collaboration: One college, many partners. Washington DC: Annual Meeting of the American Association of Colleges for Teacher Education. (ERIC Document Reproduction Service No. ED 429 933)

Burk, J., Ford, M. B., Guff, T., \& Mann, G. (1996, Feb.). Reconceptualizing student teaching: A step forward. Chicago, IL: Annual Meeting of the American Association of Colleges for Teacher Education. (ERIC Document Reproduction Service No. ED 394 915)

Carnegie Forum on Education and the Economy, (1986). A nation prepared. Teachers for the 21st century: The report of the task force on teaching as a profession. Washington, DC: Carnegie Forum.

Clarken, R. H. (1999). University/school collaboration: A case study. Washington DC: Annual Meeting of the American Association of Colleges for Teacher Education. (ERIC Document Reproduction Service No. ED 429080 ) 
Costa, A. L., \& Garmston, R. J. (1994). Cognitive coaching: A foundation for renaissance schools. Norwood, MA: Christopher-Gordon.

Ganzer, T. (2002). Sharing a cup of coffee is only a beginning. Journal of Staff Development, 23(4), 28-32.

Gersten, R., Vaughn, S., Deshler, D., \& Schiller, E. (1997). What we know about using research findings: Implications for improving special education practice. Journal of Learning Disabilities, 30, 52-66.

Glaser, B. G., \& Strauss, A. (1967). The discovery of grounded theory: Strategies for qualitative research. Chicago, IL: Aldine.

Goodlad, J. (1993). School-university partnerships and partner schools. Educational Policy, 7, 24-39.

Grimmett, P. P., \& Crehan, E. P. (1992). The nature of collegiality in teacher development: The case of clinical supervision. In A. Hargreaves \& M. Fullan (Eds.), Teacher development and educational change (pp. 5685). London: Falmer Press.

Hackmann, D. G., \& Berry, J. E. (1994). A university/school collaborative model for systemic change through site-based management. Washington DC: National Conference on School/College Collaboration of the American Association for Higher Education. (ERIC Document Reproduction Service No. ED 377 792)

Hargreaves, A., \& Dawe, R. (1990). Paths of professional development: Contrived collegiality, collaborative culture, and the case of peer coaching. Teaching and Teacher Education, 6(3), 227-241.

Harriman, N. (1998). Revitalizing teacher preparation through shared assessment practices. Teaching and Change, 6(1), 21-34.

Himel, M., Hall, M., Henderson, V., \& Floyd, R. (2000). A unique partnership: Year 1 as a professional development school in an urban environment. Teaching and Change, 8(1), 65-75.

Holmes Group, (1990). Tomorrow's schools: A report of the Holmes Group. East Lansing, MI: Author.

Liberman, A., \& Miller, L. (1990). Teacher development in professional practice schools. Teachers College Record, 92, 105-122.

Maxson, S., \& Schwartz, D. (2001). School-university collaboration for reform in California: The DELTA project. The Clearing House, 74(5), 251-256.

Pajak, E., \& Glickman, C. (1989). Informational and controlling language in simulated supervisory conferences. American Educational Research Journal, 26(1), 93-106.

Patterson, R. S., Michelli, N. M., \& Pacheco, A., (1999). Centers of pedagogy. New structures for educational renewal. Agenda for education in a democracy series (Vol. 2). San Francisco, CA: Jossey-Bass. 
D. Smith

Poole M. G., \& Okeafor, K. R. (1989). The effects of teacher efficacy and interactions among educators on curriculum implementation. Journal of Curriculum and Supervision, 4(2), 141-161.

Prawat, R. S., (1993). The role of the principal in the development of learning communities. Wingspan, 9(2), 7-9.

Reitzug, U. C., \& Burrello, L. C. (1995). How principals can build self-renewing schools. Educational Leadership, 52(7), 48-50.

Richardson, J. (1998). We're all here to learn. Journal of Staff Development, 19(4), 49-55.

Ross, D., Brownell, M., Sindelar, P., \& Vandiver, F. (1999). Research from professional development schools: Can we live up to the potential? Peabody Journal of Education, 74 (3-4), 209-223.

Rutherford, W. (1986). Teachers' contributions to school improvement: Reflection on fifteen years of research. R\& D report 3219. (ERIC Document Reproductions Service No. ED 271 462)

Rymer, J. (2002). Only connect: Transforming ourselves and our discipline through co-mentoring. Journal of Business Communication, 39(3), $342-363$.

Sandholtz, J., \& Dadlez, S. (2000). Professional development school trade-offs in teacher preparation and renewal. Teacher Education Quarterly, 27(1), 7-27.

Sheppard, B. (1996). Exploring the transformational nature of instructional leadership. Alberta Journal of Educational Research, 42(4), 325-344.

Slick, S. (2002). Teachers are enthusiastic participants in a learning community. The Clearing House, 75(4), 198-201.

Sparks, D. (2002). Inner conflict, inner strengths. Journal of Staff Development, 23(3), 66-71.

Teitel, L. (1994). Can school-university partnerships lead to the simultaneous renewal of schools and teacher education? Journal of Teacher Education, 45, 245-52.

Teitel, L. (1997). Professional development schools and the transformation of teacher leadership. Teacher Education Quarterly, 24(1), 9-22.

Terehoff, I. (2002). Elements of adult learning in teacher professional development. NASSP Bulletin, 86, 65-77.

Trubowitz, S., \& Longo, P. (1997). How it works: Inside a school-college collaboration. The series on school reform. New York: Teachers College Press.

Valli, L., Cooper, D., \& Frankes, L. (1997). Professional development schools and equity: A critical analysis of rhetoric and research. In M. Apple (Ed.), 
Review of research in education (Vol. 22, pp. 251-304). Washington, DC: American Educational Research Association.

Vare, J. W. (1997). Research as relationship: Ethics and school-university collaboration. Athens, Georgia: International Conference on Qualitative Research in Education (ERIC Document Reproduction Service No. ED 418059 ).

Watson, N., \& Fullan, M. (1992). Beyond school district-university partnerships. In M. Fullan \& A. Hargreaves (Eds.), Teacher development and education change. Washington, DC: Falmer.

Weasmer, J., \& Woods, A. (1999). Peer partnering for change. Kappa Delta Pi Record, 36(1), 32-34.

Whitaker, T. (1999). Seizing power from difficult teachers. High School Magazine, 7(2), 36-39.

Wolf, K., Whinery, B., \& Hagerty, P. (1995). Teaching portfolios and portfolio conversations for teacher educators and teachers. Action in Teacher Education, 17(1), 30-39. 